\begin{tabular}{c} 
Volume and Issues Obtainable at Center for Sustainability Research and Consultancy \\
Journal of Business and Social Review in Emerging Economies \\
ISSN: 2519-089X (E): 2519-0326 \\
Volume 6: No. 4, December 2020 \\
CSRட \\
Journal homepage: $\underline{\text { www.publishing.globalcsrc.org/jbsee }}$ \\
\hline
\end{tabular}

\title{
Environmental Disclosures and Environmental Management Strategies - A Study of Pakistani Listed Companies
}

\author{
${ }^{1}$ Waris Ali, ${ }^{2}$ Muhammad Abdul Basit Memon, ${ }^{3}$ Muhammad Mudassar Anwar, ${ }^{4}$ Rehana \\ Kouser \\ ${ }^{1}$ Associate Professor Department of Business Administration, University of Sahiwal, Sahiwal, \\ Pakistan, waris.ali@uosahiwal.edu.pk \\ ${ }^{2}$ Assistant Professor, Department of Business Administration, Sukkur IBA University, Sukkur, \\ Pakistan, basit.memon@iba-suk.edu.pk \\ ${ }^{3}$ Assistant Professor, Department of Commerce, University of Kotli, Kotli, Pakistan, \\ mudassarswati@yahoo.com \\ ${ }^{4}$ Professor, Department of Commerce, Bahauddin Zakariya University, Multan Pakistan \\ rehanakousar@bzu.edu.pk
}

\begin{abstract}
ARTICLE DETAILS
History

Revised format: November

2020

Available Online: December

2020

\section{Keywords}

Environmental Disclosure,

Environmental Management

Strategies, Developing

Country, Legitimacy Theory
\end{abstract}

\section{JEL Classification \\ M10, M14}

Oxecess

\begin{abstract}
The main purpose of this paper is to understand the environmental disclosure by listed companies of Pakistan in the light of legitimacy theory. Furthermore, it highlights the environmental management strategies pursued by them. This research used a content analysis research method to codify the reported information in the annual reports into the environment related themes. The data analysis results revealed that the sampled companies appear to give little importance to environmental issues. The companies which have disclosed mainly reported about 'environmental pollution', 'energy', and 'conservation of natural resources' themes; and provided declarative types of disclosure about them. As for as environmental strategies are concerned only a few non-financial companies have followed proactive environmental strategies and made real efforts to address environmental issues. These results seem to reflect that the companies have disclosed environment related information in the annual reports in order to legitimize their existence.
\end{abstract}

(C) 2020 Center for Sustainability Research and Consultancy Pakistan under a Creative Commons Attribution-NonCommercial-ShareAlike

4.0

Corresponding author's email address: rehanakousar@bzu.edu.pk

Recommended citation: Ali, W., Memon, M. A. B., Anwar, M. M. \& Kousar, R. (2020).

Environmental Disclosures and Environmental Management Strategies - A study of Pakistani Listed companies. Journal of Business and Social Review in Emerging Economies, 6(4), 1237-1253

\section{Introduction}

Since the last 30 years, the environmental impact of companies' activities has become a matter of great concern for various parties in a society for example environmental groups, customers, local communities, legislators, and public authorities. The societal demands for safe and clean environment, along with environmental regulations, have forced companies to undertake and implement extensive environmental management programs (see Alcaraz-Quiles et al., 2014). These 
institutional pressures have greatly influenced the large companies' environmental disclosure and environmental management strategies (see Brown and Deegan, 1998; Cormier and Magnan, 2003). This paper investigates the environmental reporting practices and environmental management strategies of listed companies of Pakistan. Environmental disclosure constitutes a part of what is generally called Corporate Social Responsibility (CSR hereafter) disclosure. CSR disclosure is defined as the voluntary provision of information about a corporation's interaction with its natural and social environment (see Guthrie and Parker 1989, Deegan and Gordon 1996, Hackston and Milne 1996, O’Dwyer 2002). CSR disclosure has four dimensions: environment, human resources, products and consumers, and community involvement (see Hackston and Milne, 1996; Branco and Rodrigues, 2008). As mentioned earlier, this study focuses on environmental disclosure which actually indicates that how an organization treats and interacts with its natural environment.

Previous disclosure studies have pointed out that the disclosure of environmental information is a country dependent phenomenon as studies on different countries produced different results (see Gray et al., 1995a; Islam and Deegan, 2008). This is perhaps the valid reason for presenting disclosure results from another developing country context i.e. Pakistan. Tsang (1998) pointed out that most of the extant literature about environmental disclosure focused on developed countries. The similar was echoed by Newson and Deegan (2002), Belal and Momin (2009), and Fifka (2013) stating that most of the disclosure studies focused on the experience of Australia, the United States, and the Europe. Studies such as: Tsang (1998) have argued that developing countries are at a greater risk in environmental areas due to the low level of interest of relevant publics in environmental issues. It is really precarious to generalize the results of developed countries over developing countries. Scholarships such as: Gray et al., (1996) and De-Villiers and Van-Staden (2006) have argued that studies on social and environmental disclosure are very necessary in developing country contexts due to the presence of multinationals in these countries. Therefore this study is set out to examine the environmental disclosure by listed companies from a developing country context i.e. Pakistan and also highlights the environmental management strategies pursued by them.

This research contributes to the existing literature in the following ways.

- It adds to the environmental disclosure literature about the developing countries in general and about Pakistan in particular as the academic research has identified the need for more studies in the field of CSR disclosure in the context of other developing countries (see Ghazali, 2007; Belal \& Momin, 2009; Haji, 2013; Kansal et al., 2014).

- It also contributes to the literature by highlighting the environmental management strategies pursued by the listed companies of Pakistan as previous disclosure literature mainly focuses on describing environmental disclosures (see Deegan and Gordon, 1996; Albertini, 2014).

- It adds to the literature by examining the quality of disclosure by categorising the environmental disclosure into general (i.e. aims and intentions indicators) and specific categories (performance indicators). Studies that examine the quality of disclosure award highest score to specific disclosure (see Cormier \& Magnan, 2005; Bouten et al., 2011; LaanSmith et al., 2005; Van Staden \& Hooks, 2007).

The remainder of this paper is organized as: the next section presents the literature review and the second section describes the context of this study. The third section discusses the theoretical framework of this research followed by its methodology. The penultimate section discusses the data analysis results. The last section provides the discussion of results.

\section{Environmental Disclosure Studies in Developing Countries}

Previous studies on developing countries predominantly focused on Malaysia, South Africa, Taiwan, and India (Amran \& Devi, 2008; Haniffa \& Cooke, 2005; Huang \& Kuang, 2010; Singh \& Ahuja, 1983) and largely reported descriptive types of disclosures (e.g. Savage, 1994; Belal \& Momin, 2009; Sobhani et al., 2009; Mahadeo et al., 2011b). These studies have shown that developing country companies are more concerned about human resource related activities than community involvement and environment related issues (e.g. Belal, 2001; Gao et al., 2005; Haniffa \& Cooke, 2005; Ratanajongkol et al., 2006). It has also been found that these companies paid considerably less attention to environmental issues as compared to the companies in developed countries (Belal \& 
Owen, 2007; Elijido-Ten, 2009). The factors examined by the studies in developing countries fall within the categories of company characteristics, general contextual factors and internal contextual factors. In the company characteristics category, consistent with the developed countries, the most commonly examined determinants are corporate size, corporate industry, and corporate financial performance and found them to be influencing CSR disclosure (see Singh \& Ahuja, 1983; Haniffa \& Cooke, 2005; Tagesson et al., 2009). In the general contextual category, consistent with the developed countries, national contextual factors resulted in variation in CSR disclosure among the developing countries (see Williams, 1999; Kamla, 2007; Wanderley et al., 2008). Further, CSR reporting agenda in developing countries is derived by external forces/powerful stakeholders e.g. international buyers (see Belal \& Owen, 2007; Islam \& Deegan, 2008), foreign investors (Teoh \& Thong, 1984; Belal \& Owen, 2007; Khan et al., 2013; Chiu \& Wang, 2014), international media (Islam \& Deegan, 2008), international regulatory bodies i.e. World Bank (see Rahaman et al., 2004), and government regulations (see Tsang, 1998; Amran \& Devi, 2007 \& 2008; Huang \& Kung, 2010). Furthermore, in contrast to developed countries, corporations in developing countries perceive a little pressure from the local public for CSR disclosure (see Belal \& Owen, 2007; Belal \& Cooper, 2011; Momin \& Parker, 2013). In the internal contextual factors category intention to build company image (see Belal \& Owen, 2007; Momin \& Parker, 2013), cost of reporting CSR information (Mitchell \& Hill, 2009; Belal \& Owen, 2007), non-availability of CSR data and a lack of motivation (De-Villiers, 2003; Mitchell \& Hill, 2009) do influence CSR disclosure in developing countries.

\section{Pakistani Context}

Pakistan is a South Asian developing country. It is an economically weak country and facing many social (e.g. illiteracy, unemployment, poverty and weak law enforcement etc.) and environmental (e.g. environmental pollution and waste mismanagement etc.) problems. Every government, except the government led by 'Pakistan Peoples Party (PPP)' in 1972-77, followed the principles of a market economy and focused on industrial growth. In the last six decades (1955/56 to 2010/11) manufacturing and the other sectors (excluding agriculture sector) of Pakistan have experienced overall average annual growth of $6.40 \%$ and $5.50 \%$ respectively (Pakistan Bureau of Statistics, 2011). As a result, 648 large public (financial and non-financial) companies now operate in Pakistan and are listed at different stock exchanges of Pakistan, including KSE, LSE, and ISE (SECP, 2011). The growth in different sectors resulted in an average annual GDP growth of $4.87 \%$ in the last six decades (Pakistan Bureau of Statistics, 2011) and resulted in an increase in GNI per capita from $\$ 340$ in 1980 to $\$ 1260$ in 2012. In addition to this, manufacturing and other sectors (excluding agriculture sector) accommodate $53.35 \%$ of the employed persons in Pakistan (see Pakistan Bureau of Statistics, 2011).

Despite corporations' contribution to the national economy, some corporations have caused, among others, various environmental problems in the country. According to SDPI (2012) 20\% of the registered industries in Pakistan are considered highly pollution intensive and creating environmental pollution. It can also be seen from the example of leather tanneries, an export oriented industry of Pakistan, found to be involved in polluting the water which resulted in massive protest from the local community (see Lund-Thomsen \& Nadvi, 2010). Similarly, a survey by the federal environmental protection agency showed that leather tanneries located in Kasur and Sialkot are discharging effluents having chrome concentration $182-222 \mathrm{mg} /$ litre that is much higher than the standard level of the government i.e. $1 \mathrm{mg} / \mathrm{litre}$ (PEPA, 2005a).

To govern the corporate environmental issues, the regulatory framework of Pakistan consists of various laws. The main laws regarding the protection of the environment are the Environmental Protection Act 1997, the Pakistan Penal Code 1860, and the Factory Act 1934. Under these rules and regulations, certain guides and standards have been established to protect the environment, including the control of pollution and hazardous waste. These laws are implemented by the Environmental Protection Agency (EPA), a department working under the Ministry of Climate Change of Pakistan.

\footnotetext{
${ }^{1} 44.65 \%$ of employed persons are working in the agriculture sector of Pakistan (see Pakistan Bureau of Statistics, 2011).
} 
The laws mentioned above require companies, among others, to protect the environment rather than requiring companies to disclose information about the actions taken to protect environmental rights.

The disclosure regulatory framework of Pakistan consists of the Companies Ordinance 1984, the International Financial Reporting Standards (IFRS), the Accounting and Financial Reporting Standards (AFRS) and the Codes of Corporate Governance (see SECP, 2014), and mainly focus on the reporting of financial information and pays little attention to the disclosure of environmental performance. Although the SECP has introduced a law (i.e. CSR order 2009), which requires companies to disclose information about their CSR activities. The CSR Order 2009 only highlights the general items which may be reported by a company to express its CSR performance in the annual report (see CSR Order, 2009) rather than specifying the format of CSR report and indicators to be reported by a company, as is the case in financial reporting, in order to demonstrate their accountability to a broad stakeholders other than shareholders. This Order requires listed companies of Pakistan to report only two items about environmental issues (see CSR Order, 2009). This highlights that there is insufficient regulatory requirements to govern corporate environmental disclosure in Pakistan. It has been argued that Pakistan lacks effective state mechanisms to control environmental pollution in the country (Asian Development Bank, 2006). It has also been reported that the Pakistani government lacks capacity (and sometime political will) for monitoring the social and environmental performance of companies (see Lund-Thomsen et al., 2006; SDPI, 2012). The above discussion demonstrates that the legal system of Pakistan recognises the protection of environmental rights, but the enforcement of these laws is seen as weak in Pakistan.

In the absence of effective state mechanisms to control corporate environmental pollution various groups (e.g. the NGOs, media, and employees etc.) in Pakistan have demanded companies to adopt socially responsible behaviour. This may drive companies operating in Pakistan, as noted in other developing countries such as: Bangladesh (see Islam and Deegan, 2008; Belal and Owen, 2007), to address their associated social and environmental problems. In the increasing demands from various groups in the society, the companies may disclose their CSR related information including environmental disclosure in order to legitimize their continued existence.

\section{Theoretical Framework}

In this research both legitimacy theory and literature on environmental strategies serve as a framework. Legitimacy theory is used to explain environmental disclosures by the listed companies of Pakistan while the literature on environmental management strategies is used as a guide to determine environmental strategies pursued by them. Legitimacy theory views an organization as a part of a broader social system (under social contract see Shocker \& Sethi, 1974) where an organization has influence on and influenced by the other actors, part of the social system (see Islam and Deegan, 2008; Reverte, 2009). To remain the part of a social system a corporation is expected to conform to the norms, values, and beliefs of the given system (see Deegan and Unerman, 2011). A corporation is considered as a legitimate company if the actions/practices taken by the corporation do conform to the expectations of the society in which the firm is operating (see O'Donovan, 2002). On the other hand, if a society's perception about the corporation's actions does not match with the society's expectations a legitimacy gap will occur (see O'Donovan, 2002) that may bring negative consequences to that firm e.g. consumers boycott of a company's products and/or public demonstrations against the company and/or result in governmental fines etc. (see Deegan and Unerman, 2011). To minimize the legitimacy gap, a company may opt different strategies for example 'to educate the society', 'to alter the society's perceptions about the corporate activities', 'to alter the society's expectations about the corporate activities', and 'to divert the attention from the main issue of concern' (Lindblom, 1993). These strategies may be targeted to gain, maintain, or repair legitimacy (Suchman, 1995) and each of the strategy requires disclosure of information (see Dowling and Pfeffer 1975). Thus under this theory, CSR disclosure is considered as a tool to conform to the expectations of the society (see Branco and Rodrigues, 2008) in order to gain, maintain, or repair legitimacy.

Legitimacy can be understood in detail from a study by Suchman (1995) who identified three types 
of legitimacy: pragmatic legitimacy, moral legitimacy, and cognitive legitimacy. Pragmatic legitimacy rests on the self-interested calculations of an organization's most immediate audience and the immediate audience is involved in direct exchange with an organization. According to Clarkson (1995) customers, suppliers, employees, and the local group (the government and the local communities) are involved in transaction with the firm so these groups can be considered as a firm's immediate audience. Moral legitimacy relies on managerial judgment that organizational activities are "the right thing to do" or organizational activities are promoting societal welfare (Mahadeo et al., 2011b; Suchman, 1995). In securing moral legitimacy companies disclose pro-social activities and/or show their alliance with social imperatives (e.g. alleviation of poverty) (Mahadeo et al., 2011b). Further, to explain the moral legitimacy Suchman (1995) discussed sub-constructs: consequential legitimacy (judged based on what the organization has accomplished e.g. amount of donation, amount of pollution reduced, and amount of waste handled etc.), procedural legitimacy (based on embraced socially accepted techniques and procedures e.g. adopting best practices to help the needy), and structural legitimacy (based on the presence of morally accepted structural characteristics e.g. CSR department, CSR committee, and quality control department etc.). The third form of legitimacy is not based on interest or evaluation but based on managers' cognition. This type of legitimacy can be achieved through conforming to established standards and models of ethics prevalent in that society (Mahadeo et al., 2011). Thus, from the above discussion, it can be argued that the disclosure of different types of information by a company can be seen as an attempt to gain pragmatic, moral, and/or cognitive legitimacy.

\section{Literature on Environmental Management Strategies}

To determine the environmental management strategies implemented by corporations, academic research has presented several frameworks which mainly fall into two categories: sequential and nonsequential approach to environmental management (Albertini, 2014). Sequential approach to environmental management consists of several stages ranges from non-compliance to proactivity (see Hunt and Auster, 1990; Roome, 1992). A 'non-compliance' strategy occurs when a company has not developed an environmental policy at all either intentionally or by managerial default to address the requirements of law and social pressures (Albertini, 2014). The non-compliance environmental strategy of a corporation can be determined by the number of indicators such as environmental penalties, accidents, or lawsuits regarding non-compliance with regulatory requirements (Thomas, 2001; Lorraine et al., 2004).

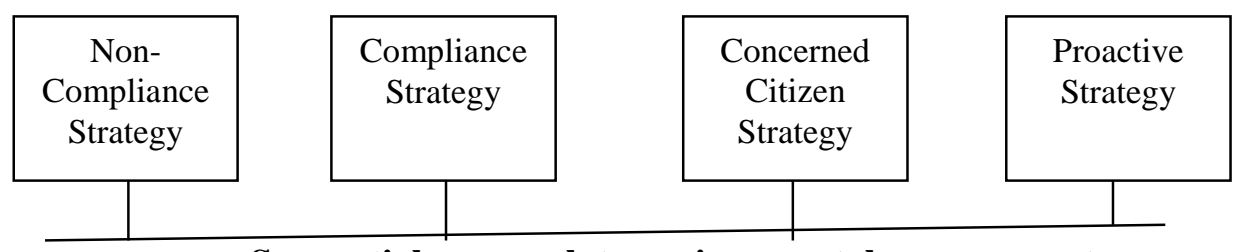

Sequential approach to environmental management

A 'compliance' strategy occurs when a company pursues an environmental policy to a minimum level in order to avoid litigation or loss of market share (Hunt and Auster, 1990). A company pursuing this strategy may report about air, water and waste pollution resulting from its manufacturing processes in order to satisfy the government and its relevant stakeholders (Roome, 1992). In this case environmental performance is generally measured through pollution control indexes such as greenhouse gas emissions, effluents and waste management (Albertini, 2014).

'Concerned citizen' companies normally go beyond regulatory requirements and usually implement voluntary environmental management programs. Such a company focuses on reducing waste and toxic emissions, conserving energy and other natural resources, reducing and recycling solid waste and, finally, reducing the impact of business activities on the eco-system (Hunt and Auster, 1990). In this situation environmental performance is usually measured by the amount of environmental investment, the initiation of a pollution prevention program, or the participation in voluntary environmental management programs (Albertini, 2014). 
A 'proactive' company places great emphasis on environmental management systems by focusing on development of capabilities regarding waste minimisation and green product design (Hunt and Auster, 1990). The implementation of such environmental management systems (EMS) is made to enhance corporate environmental performance (Hassel et al., 2005). In this case environmental performance can be judged by several indicators such as the proportion of output generated using less pollution intensive processes, environmental training of employees, the number of eco-friendly products produced, and the modification in manufacturing processes (Albertini, 2014).

In non-sequential approach to environmental performance, companies choose their environmental commitments and pursue approaches with regard to different environmental issues at present (Christmann and Taylor, 2002). Such a company can have an opportunistic attitude towards environmental issues and can adopt a restrained, speculative, or conditional commitment (Albertini, 2014). In the case of opportunistic strategies, environmental performance is mostly measured by widespread disclosure about environmental awards, cleaner practices, environmental standards, and partnership with non-governmental organizations (Albertini, 2014). In summary environmental management strategies pursued by companies, whether sequential or non-sequential, are reported through CSR disclosure indictors. Despite several environmental management strategies discussed above, Albertini (2014) has only used three strategies: compliance, opportunistic, and proactive in order to make the analysis simple. Consistent with Albertini (2014), this research also rely on these strategies for the analysis of environmental disclosure made by listed companies of Pakistan. As mentioned earlier, a compliance strategy is measured by the amount of water and energy consumed, the number of environmental penalties, the extent of waste management, and/or the amount of effluents discharged. An opportunist strategy is measured by environmental charter or sponsorship, environmental awards, and extra financial rating, while a proactive strategy is measured by a proportion of output generated using less pollution intensive processes, environmental training of employees, the number of eco-friendly products produced and the modification of manufacturing processes.

\section{Methodology}

This research uses a content analysis research method to codify the reported information in the annual reports into the environment related themes. The environmental disclosure instrument was developed from Hackston and Milne (1996) and later on updated based on the environmental information reported in the annual reports of thirty leading companies of Pakistan. The final environmental disclosure instrument consists of five themes: environmental pollution control programs, preservation of natural resources, conservation of energy, aesthetics development programs, and other environment related information. Each theme has further three categories: aims, actions, and performance indicators, which serve as a base for examining the quality of environmental disclosure. Aims/ intentions category covers companies' policies and general types of disclosures about a theme. The action category covers activities performed by a company to accomplish its aims/intentions. The performance category contains information about the inputs (e.g. amount and time spent on the protection of environment etc.), the outputs (e.g. number of people benefited and pollution reduced etc.) and the third party evidences (e.g. environmental awards and survey results etc.) (for details see Vuontisjärvi 2006, Bouten et al., 2011). The aims and actions categories of a theme consist of declarative types of disclosure whereas the performance category of a theme covers both monetary and non-monetary quantitative evidences. The types of information disclosed about a theme can be better explained by the following examples. For example: a corporation reports that they are committed to reduce pollution and that they have installed a carbon collection plant, worth Rs.50million, which reduced 20 tons of carbon dioxide (tCO2e). With the help of this example, the following table explains the three types of information.

Table 1: Types of information about a theme

\begin{tabular}{llll}
\hline Example & Aims/Intentions & Actions & Performance \\
\hline Item 1 & To reduce & Installation of carbon & Reduced 20tCO2e (measured in \\
pollution & collection plant & $\begin{array}{l}\text { outcome terms) \& Rs.50million } \\
\text { (measured in input term) }\end{array}$ \\
\hline
\end{tabular}


After the finalization of this research instrument, it was used by the two coders to code the environment related information in the annual reports of listed companies selected into the sample. This research selected a sample of 120 listed companies (see Table 3) by including all the companies whose annual reports were available for the year 2011 on their respective websites or on the KSE website. This research used Krippendorf's Alpha statistical measure to check inter coder reliability and the results showed convincing evidence of inter-coder reliability because all the environment related themes have Krippendorf's Alpha value greater than 0.851 (for interpretation see Table 2). The discrepancies found between the two coders were later resolved through mutual discussion. The annual reports were selected as a source of information for content analysis due to their easily accessibility and credibility. Annual reports were also used as source of information for content analysis in the previous disclosure studies (see Amran \& Devi 2007; Belal 2001; Hackston \& Milne 1996; Haniffa \& Cooke 2005). One important point to mention here is that the quantity of environmental disclosure is measured, as consistent with the previous studies (see Hackston and Milne, 1996; Sobhani et al., 2009), by counting the number of sentences reported to express a company's environment related efforts.

Table 2: Krippendorff's Alpha Value Interpretation

\begin{tabular}{cl}
\hline Krippendorff's Alpha Value & Interpretation \\
\hline$<0$ & Poor agreement \\
$0.0-0.20$ & Fair agreement \\
$0.21-0.40$ & Slight agreement \\
$0.61-0.80$ & Substantial agreement \\
$0.81-1.00$ & Almost perfect agreement \\
\hline & Adopted from Seppanen (2009)
\end{tabular}

Table 3: The Sample Description

\begin{tabular}{lc}
\hline Description & Number of companies \\
\hline Manufacturing Firms: Manufacturer of textiles, chemicals, foods, non- & $\mathbf{6 7}(\mathbf{5 5 . 8 3 \%})$ \\
metallic minerals, electrical equipments, motor vehicles, trailers and semi- \\
trailers, refined petroleum products, basic metals, papers, pharmaceuticals, \\
tobacco, and rubber and plastics products \\
$\begin{array}{l}\text { Financial and Insurance Firms: Banks, insurance, and Modarba } \\
\text { companies }\end{array}$ \\
$\begin{array}{l}\text { Other firms: Companies involved in supplying electricity, gas, steam and } \\
\text { air conditioning and companies involved in transportation and storage, } \\
\text { extraction of crude petroleum and natural gas, telecommunications, and } \\
\text { construction of buildings }\end{array}$ \\
\hline Total Firms & $\mathbf{1 2 ( 1 0 \% )}$ \\
\hline
\end{tabular}

\section{Data analysis results}

The data analysis results revealed that $47 \%$ of the sampled companies reported about environmental issues and they reported on average 4.94 (standard deviation 12.78) sentences. The sampled companies gave more attention to 'environmental pollution' theme $(28 \%)$ followed by 'energy' $(12 \%)$, 'conservation of natural resources' (8\%), and 'aesthetics' theme (4\%). In addition, 39\% of the companies disclosed other environmental related information. The results indicated that the most commonly reported indicators are: the commitment to protect the environment (38\%), the intention to abate pollution (18\%), and the intention to complying with environmental rules and regulations $(14 \%)$. The results also showed that sampled companies gave relatively more attention to the aims and actions indicators than to the performance indicators. The attention in now paid to each theme of environmental disclosure. 
Figure 1: Environmental Disclosure Themes

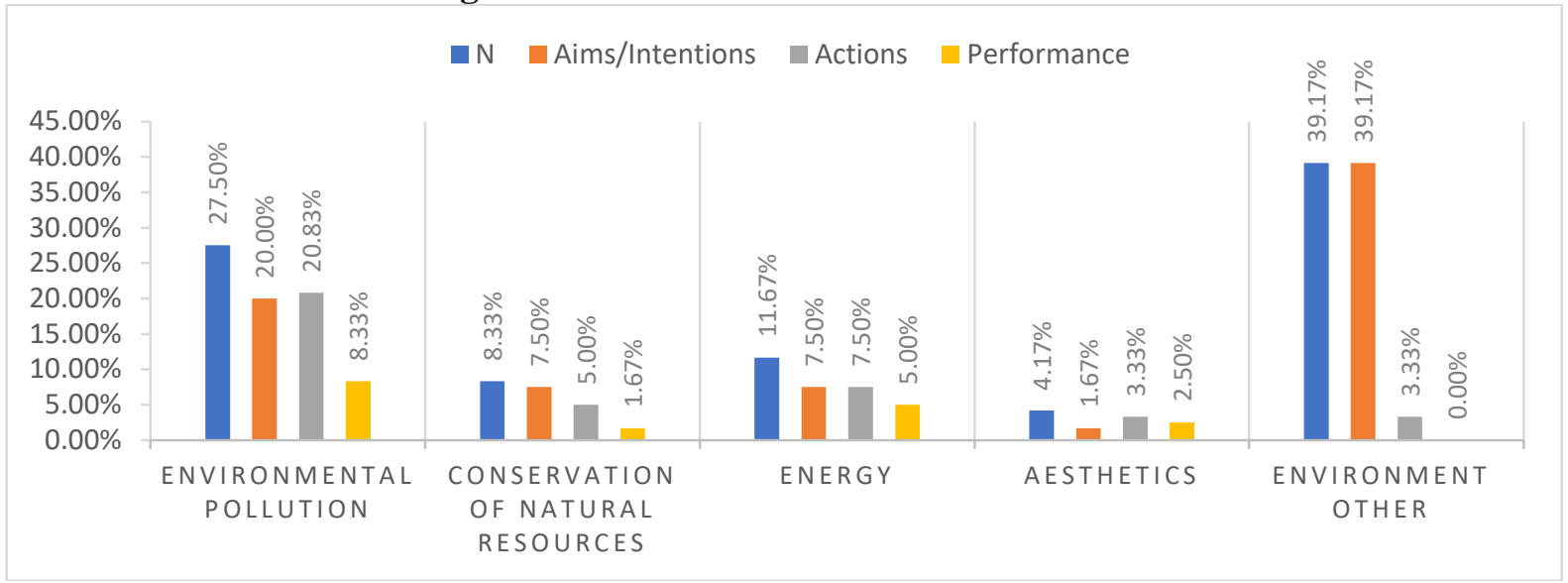

Figure 2: Most Commonly Disclosed Environmental Indicators

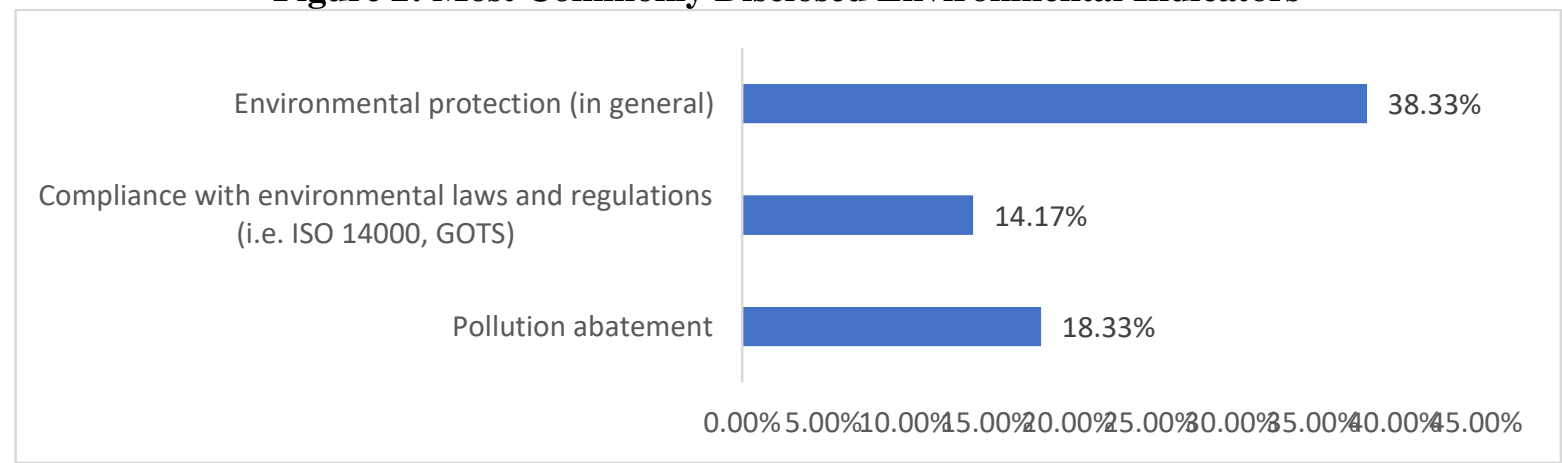

\section{Environmental Pollution Theme}

'Environmental Pollution' covers references made to control or to reduce the environmental pollution (e.g. noise and emissions etc.). Under this theme 24 companies (20\%) showed their commitment to abate pollution, 25 companies (21\%) reported information about the action indicators, while only 10 companies $(8 \%)$ disclosed information about the performance indicators. It reveals that more companies documented disclosure in the qualitative way. Here qualitative evidence means that companies are reporting information in a declarative way rather than providing quantifiable evidence. The most commonly disclosed indicators are 'companies' commitment to reduce environmental pollution' (18\%), 'compliance with environmental laws' (14\%), 'installation of new equipment' (5\%), 'environmental management system in place' $(6 \%)$, and 'environmental awards' indicators (6\%). In addition, a small number of companies reported information about other indicators such as: 'research and development' (3\%), 'anti-litter campaign' (1\%), 'trees plantation to reduce pollution' $(3 \%)$, 'noise educational programmes' $(2 \%)$, 'noise protective gadgets' $(2 \%)$, 'amount of pollution reduction' (1\%), and 'number of trees planted' $(2 \%)$. Thus the sampled companies gave more attention to expressing their commitment to reduce environmental pollution and to comply with environmental laws rather than to the actions taken and the result achieved. 
Figure 3: Environmental Pollution

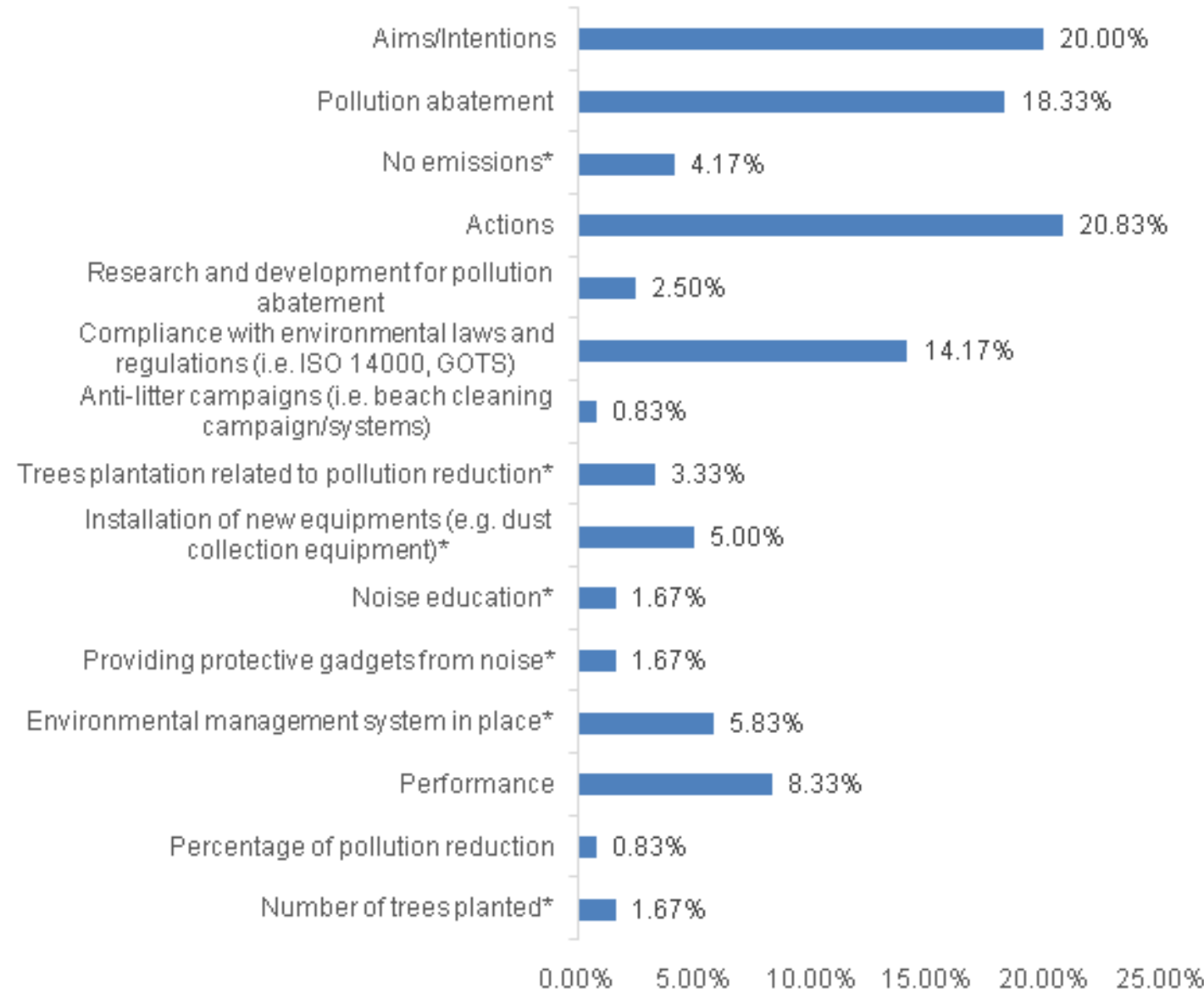

\section{Conservation of Natural Resources Theme}

'Conservation of Natural Resources' covers references made by the companies to the conservation of natural resources (e.g. water, gas, oil, and other material etc.). Relative to the environmental pollution, a small number of companies reported the conservation of natural resources theme $(8 \%)$. Under this theme, $9(8 \%), 6(5 \%)$, and $2(2 \%)$ companies disclosed information about aims, actions, and performance indicators respectively. Under this theme, a small number of companies disclosed information about 'companies' commitment to conserve natural resources' $(8 \%)$, 'water recycling' (3\%), 'usage of recycled material' (2\%), 'quantity of paper recycled' ( 1 company), and 'quantity of other natural resources saved' (1 company).

\section{Figure 4: Conservation of Natural Resources}

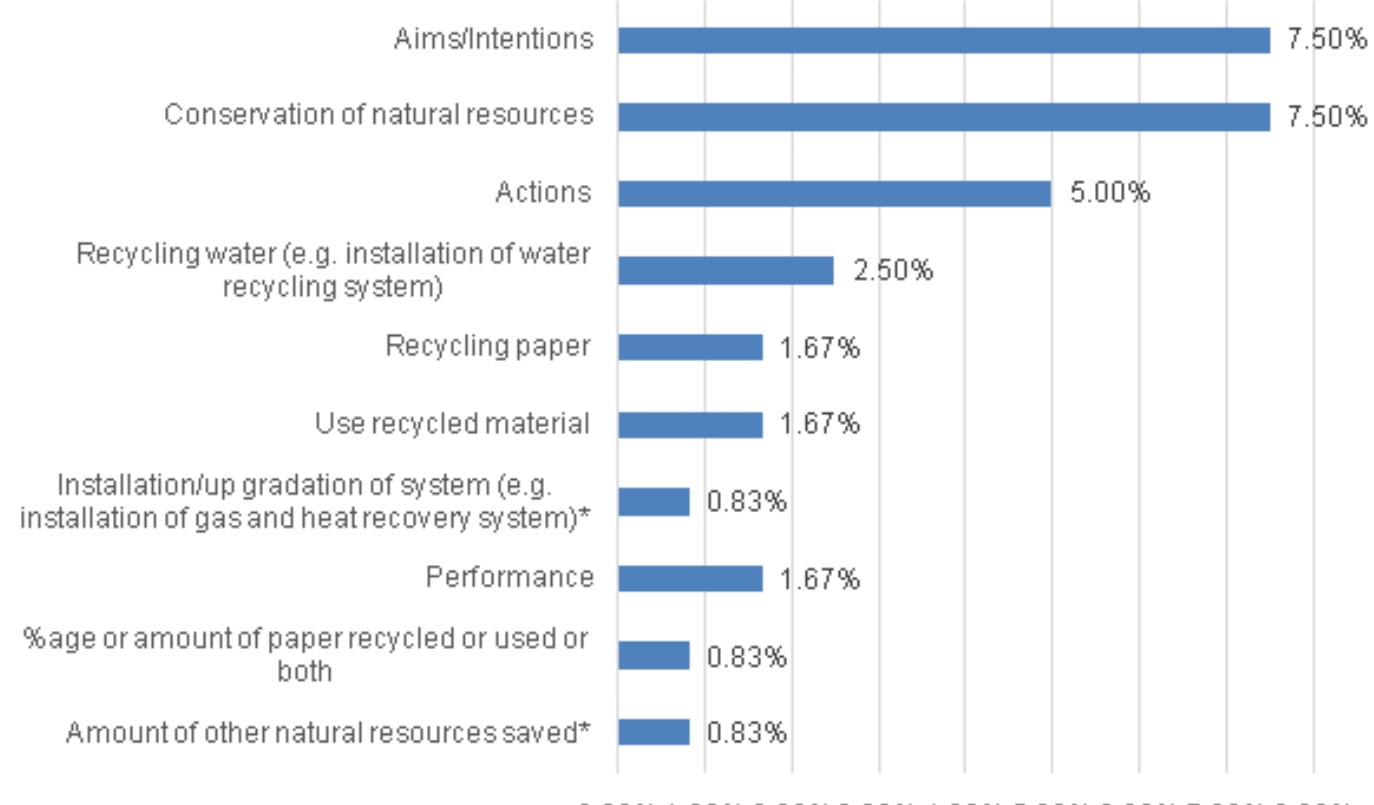


Figure 5: Energy

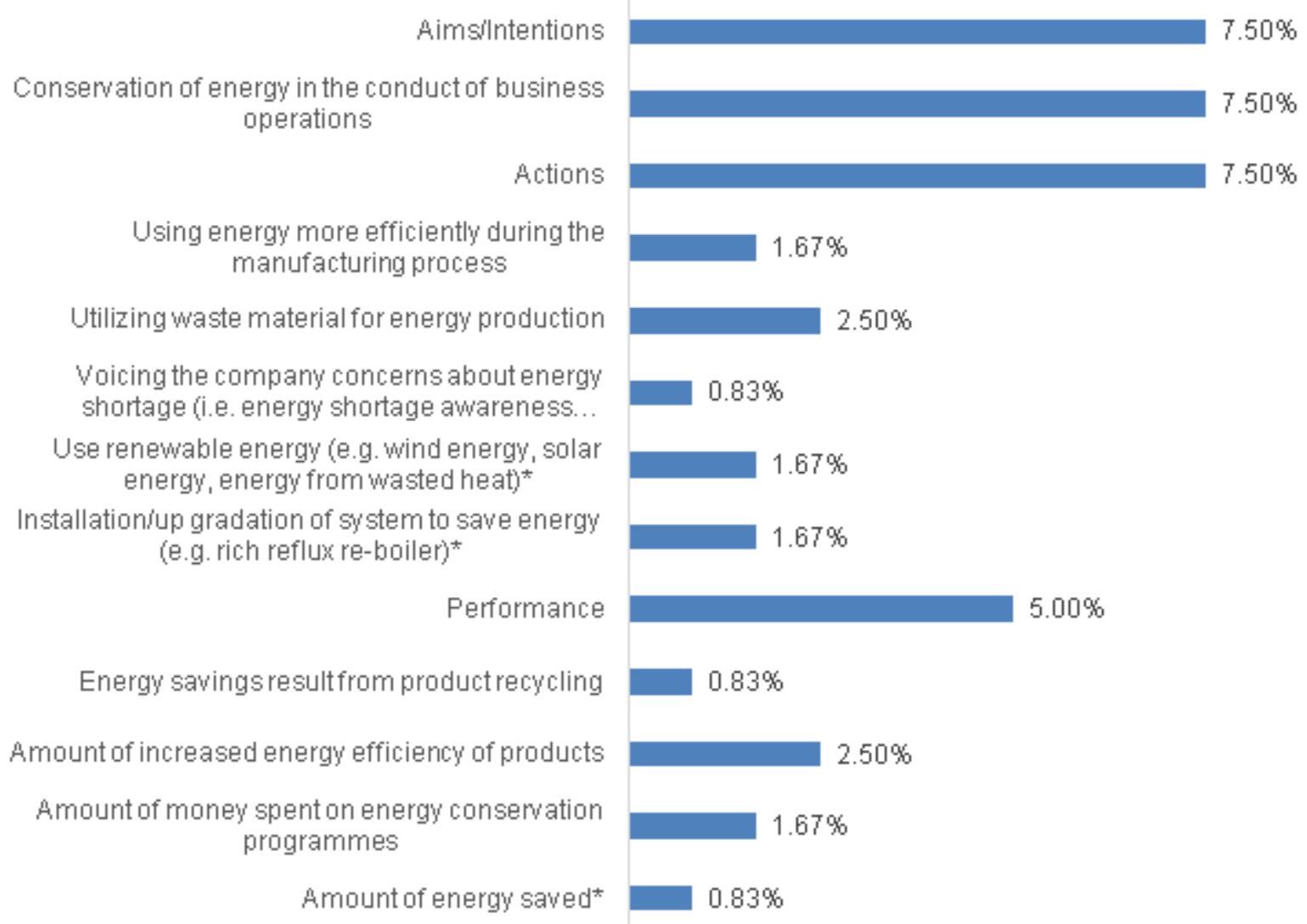

$0.00 \% 1.00 \% 2.00 \% 3.00 \% 4.00 \% 5.00 \% 6.00 \% 7.00 \% 8.00 \%$

\section{Energy Theme}

'Energy' theme encompasses references related to firms' efforts to save/conserve energy and firms' efforts for the renewable energy (e.g. wind energy and solar energy etc.). Under this theme, 9 companies $(8 \%)$ reported about their commitment to conserve energy, $8(8 \%)$ companies reported about the actions taken by them to conserve energy, and 6(5\%) companies disclosed performance indicators. Under this theme, companies disclosed about the efficient usage of energy in manufacturing process $(2 \%)$, the usage of waste material for energy production (3\%), the usage of renewable energy ( 2 companies), the up-gradation of system ( 2 companies), the expanses made on the energy conservation programmes ( 2 companies), the quantity of energy saved ( 3 companies), the energy shortage awareness programmes ( 1 company), and the energy saving results (1 company).

\section{Aesthetics Theme}

'Aesthetics' theme covers references related to firms' efforts to beautify the environment (broadly) or to make the factory green (narrowly). Relative to the other environmental disclosure themes, a small number of companies made disclosure about this theme (4\%). Under this theme, the companies reported about 'their intention to make the factory green' $(2 \%)$, 'the sponsorship of gardening and flower competition' (1 company), 'plantation of trees' (3 companies), and 'number of trees planted' (3 companies). 
Figure 6: Aesthetics

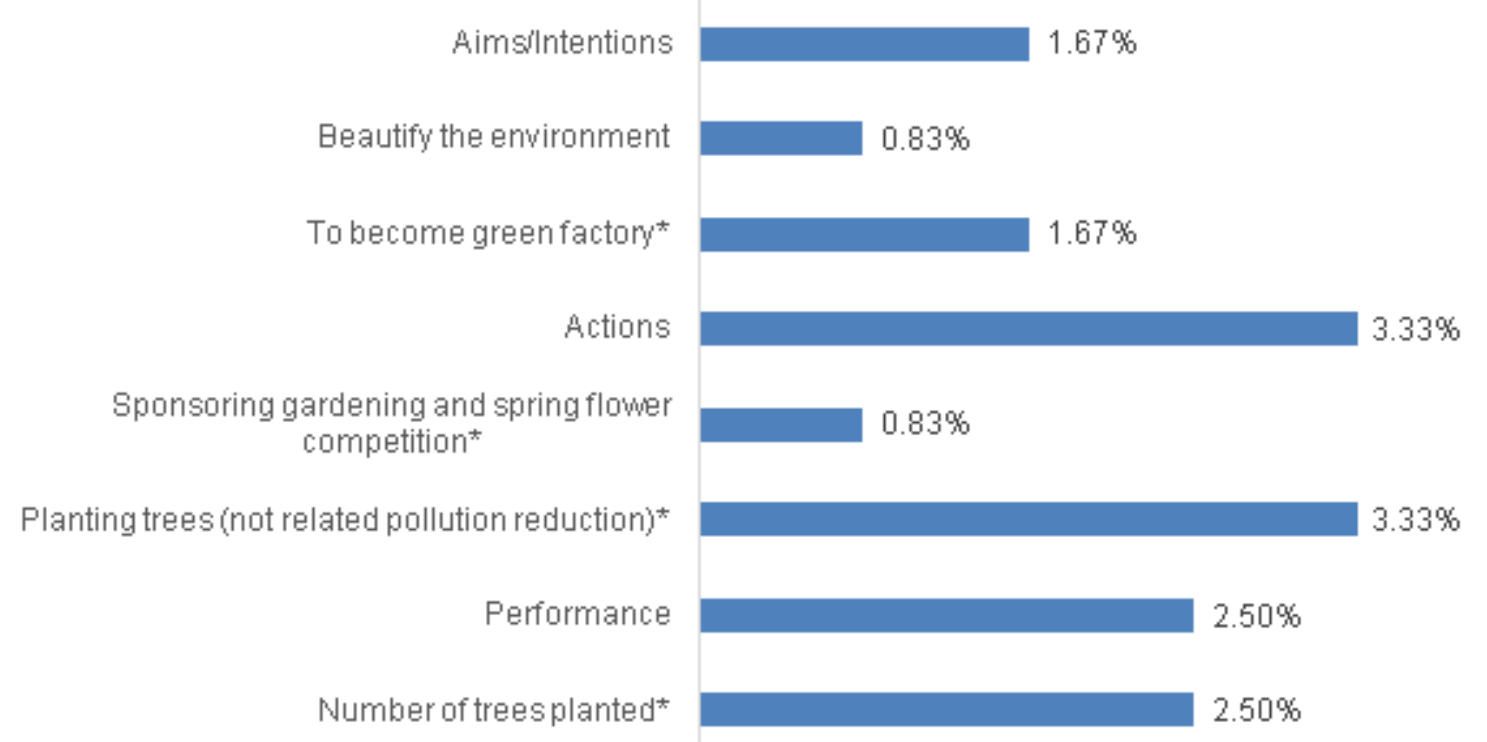

$0.00 \% 0.50 \% 1.00 \% 1.50 \% 2.00 \% 2.50 \% 3.00 \% 3.50 \%$

Figure 7: Environment Other

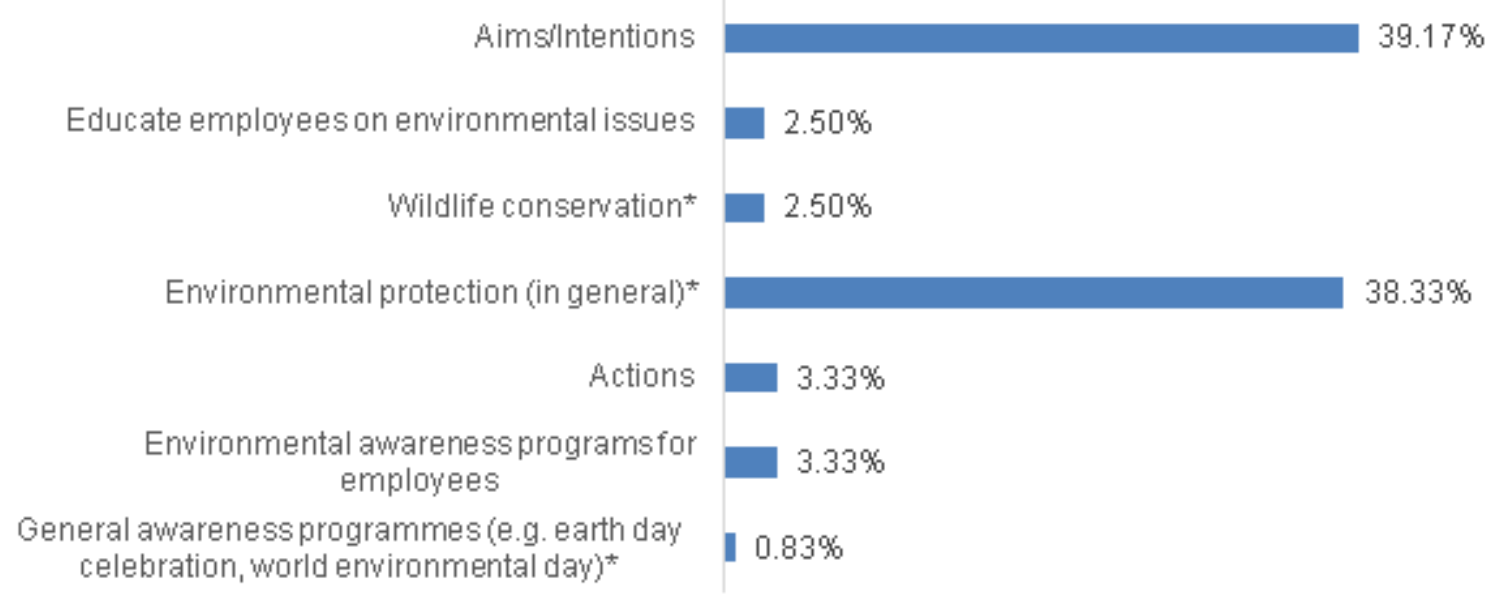

$0.00 \% 5.00 \% 0.00 \% 5.0090 .00 \% 5.00 \% 0.00 \% 5.00 \% 0.00 \% 5.00 \%$

\section{2. 'Environment other' Theme}

'Environment other' theme covers issues related to the environment, not covered by the other environmental disclosure themes. Under this theme, a large number of companies reported about 'their commitment to protect the environment' (38\%) and 'the environmental awareness programmes (e.g. earth day celebration, world environmental day) carried out by them' (4\%).

\section{Environmental Disclosure and Legitimacy Theory}

The data analysis results revealed that $47 \%$ of the sampled companies reported, on average, 4.94 (standard deviation 12.78) sentences about the environmental issues and mainly focused on 'environmental pollution', 'energy' theme, and 'conservation of natural resources' theme. The results indicated that the maximum support was received by the commitment to protect the environment in general $(38 \%)$ followed by the intention to abate the pollution (18\%), and the intention to complying with environmental rules and regulations (14\%). Contrary to the above indicators, none of the performance indicators was supported by at least 10 companies. This indicates that the listed companies made qualitative (or declarative) types of disclosure about the environmental issues. This result is consistent with an environmental disclosure study conducted in South Africa, a developing country, where the sampled listed companies made more general disclosure than specific disclosure (see De Villiers and Van Staden, 2006). This result is also consistent with another study conducted by Mahadeo et al. (2011b) where Mauritius, another developing country, listed companies also made environmental disclosure in the declarative way. Some authors in the disclosure field have argued 
that the specific environmental disclosure by the firm may attract unwanted attention of the public and may be a threat to its legitimacy (see O'Dwyer, 2002; Mahadeo et al. 2011b). Similarly some have argued that negative environmental news adversely affects the market value of the firm (see Lorraine et al., 2004; Thomas, 2001). The general disclosure, noticed in this study, shows that companies in Pakistan may be attempting to avoid scrutiny of ecological impacts of their operations. Thus listed companies of Pakistan are aiming to maintain their legitimacy.

The results also revealed that only 3 environmental disclosure indicators were reported by more than 10 sampled companies. This shows that Pakistani listed companies are less concerned about the environmental issues. The low level of concern about environmental issues can be attributed to the poor economic conditions, the high unemployment, and the poor law enforcement situation in Pakistan. In such situations, the relevant publics are usually less concerned about environmental issues. This low level of environmental disclosure, under pragmatic form of legitimacy, can be attributed to the lower level of interest of the immediate audience of the firm in environmental issues. Thus pragmatic legitimacy provides explanation for the dearth of environmental disclosure in Pakistan. $18.33 \%$ of sampled companies have given references to the abatement of pollution in the country. It indicates the companies are trying to promote social welfare by abating pollution. Thus it can be argued that companies are disclosing environmental related information to gain moral legitimacy. Some of the sampled companies have given reference to the installation of new equipment $(5 \%)$ and implementation of environmental management systems $(6 \%)$. These companies may be attempting to gain procedural legitimacy by adopting social accepted systems/practices. In addition to the above, 17 sampled companies expressed their acquisition of ISO certificates (e.g. ISO 14000). Under legitimacy theory, these companies may be attempting to gain procedural legitimacy (a type of moral legitimacy) by adapting socially accepted techniques and procedures (see Suchman, 1995). According to Bouten et al. (2011) a company may be considered as an accountable if it discloses information about three categories: aims, actions, and performance of a theme. Above presented evidence states that the most of the sampled companies' disclosure falls in the aims and actions categories of a theme. Therefore, it can be argued that the environmental disclosure by listed companies of Pakistan was not targeted to express their accountability rather provides support for legitimacy theory.

\section{Environmental Disclosure and Environmental Management Strategies}

Table 4 shows the environmental management strategies pursued by the listed companies of Pakistan. The results have shown that financial firms are paying little attention to environmental issues and have not reported about their environmental strategy. However, limited non-financial firms are appearing to pursue different environmental management strategies ranges from compliance to proactive environmental strategy. The non-financial companies which have disclosed environment related information mainly appear to follow opportunistic environmental strategies (Table 4). Under opportunistic strategy the most commonly reported indicators are environmental standards (17 companies), environmental awards ( 7 companies), trees plantation (8 companies), and installation of new equipment (6 companies). However, a very small number of companies appear to practice proactive environmental strategies. Under proactive strategy non-financial companies paid attention to installation/up gradation of system to save energy (2 companies), environmental awareness programs for employees (4), and to environmental management systems (7 companies). 
Table 4: Environmental Management Strategies

\begin{tabular}{|c|c|c|c|}
\hline Industries & Compliance Strategy & Opportunistic Strategy & Proactive strategy \\
\hline $\begin{array}{l}\text { Manufacture of textiles, chemicals, } \\
\text { foods, non-metallic minerals, } \\
\text { electrical equipment, motor vehicles, } \\
\text { trailers and semi-trailers, basic } \\
\text { metals, papers, pharmaceuticals, } \\
\text { tobacco, and rubber and plastics } \\
\text { products } \\
\text { Manufacturers of refined petroleum } \\
\text { products, } \\
\text { Companies supplying electricity, gas, } \\
\text { steam and air conditioning } \\
\text { Companies involved in transportation } \\
\text { and storage } \\
\text { Companies involved in extraction of } \\
\text { crude petroleum and natural gas } \\
\text { Telecommunication } \\
\text { Construction companies }\end{array}$ & $\begin{array}{l}\text { Percentage of pollution reduction } \\
(1) \\
\text { Recycling water e.g. installation of } \\
\text { water recycling system ( } 3) \\
\text { Recycling paper (2) } \\
\text { Use recycled material (2) } \\
\text { \%age or amount of paper recycled } \\
\text { or used or both (1) } \\
\text { Amount of other natural resources } \\
\text { saved (1) } \\
\text { Amount of energy saved (1) }\end{array}$ & $\begin{array}{l}\text { Anti-litter campaigns i.e. beach cleaning } \\
\text { campaign/systems (1) } \\
\text { Trees plantation related to pollution } \\
\text { reduction ( } 8 \text { ) } \\
\text { Number of trees planted (5) } \\
\text { Environmental awards e.g. AEEA } \\
\text { Awards, NFEH, ACCA-WWF ( } 7 \text { ) } \\
\text { Environmental Standards i.e. ISO } 14000 \\
\text { and/or GOTS (17) } \\
\text { Voicing the company concerns about } \\
\text { energy shortage i.e. energy shortage } \\
\text { awareness programmes (1) } \\
\text { Amount of money spent on energy } \\
\text { conservation programmes (2) } \\
\text { Sponsoring gardening and spring flower } \\
\text { competition (1) } \\
\text { General awareness programmes e.g. earth } \\
\text { day celebration, world environmental day } \\
\text { (1) } \\
\text { Using energy more efficiently during the } \\
\text { manufacturing process (2) } \\
\text { Utilizing waste material for energy } \\
\text { production (3) } \\
\text { Providing protective gadgets from noise } \\
\text { (2) } \\
\text { Noise education (2) } \\
\text { Installation of new equipment e.g. dust } \\
\text { collection equipment (6) }\end{array}$ & $\begin{array}{l}\text { Environmental management system in place (7) } \\
\text { Installation/up gradation of system e.g. } \\
\text { installation of gas and heat recovery system (1) } \\
\text { Use renewable energy e.g. wind energy, solar } \\
\text { energy, energy from wasted heat (2) } \\
\text { Installation/up gradation of system to save } \\
\text { energy e.g. rich reflux re-boiler (2) } \\
\text { Environmental awareness programs for } \\
\text { employees (4) }\end{array}$ \\
\hline $\begin{array}{l}\text { Banks and Insurance companies } \\
\text { Modarba companies }\end{array}$ & - & $\begin{array}{ll}- \\
-\end{array}$ & - \\
\hline
\end{tabular}

Number of companies has been mentioned in bracket 



\section{Discussion and Conclusion}

The purpose of this article is to describe the quality of environmental disclosure and associated environmental management strategies. The data analysis results revealed that the sampled companies paid least attention to environmental aspects and focused on limited themes such as 'environmental pollution', 'energy conservation', and 'conservation of natural resources'. The mainly reported indicators are the commitment to protect the environment in general (38\%), the intention to abate the pollution (18\%), and the intention to complying with environmental rules and regulations (14\%). Contrary to the above indicators, none of the performance indicators was supported by at least 10 companies. This indicates that the listed companies made qualitative (or declarative) types of disclosure about the environmental issues. This result is consistent with the studies conducted in other developing countries such as South Africa, Bangladesh, and Mauritius and pointed out that listed companies have made environmental disclosure in the declarative way (see De Villiers and Van Staden, 2006; Belal, 2001; Mahadeo et al., 2011b). This result in contrary to the studies conducted in developed countries which point out that companies in developed countries appear to disclose both declarative and quantitative information (see Cormier \& Magnan, 2003; Cormier et al., 2005; Bouten et al., 2011). The difference in types of disclosures can be attributed to the difference in magnitude of pressures from various stakeholders in developed and developing countries. The same has been pointed out by the recent research of Ali et al., (2017). They stated that developed countries companies are prone to pressures from various internal and external stakeholders such as shareholders, investors, creditors, regulators, environmentalists, and the media, while in developing countries CSR (environmental) disclosure is influenced by the pressure of only external forces/powerful stakeholders such as: as international buyers, foreign investors, international media and international regulatory bodies (e.g. the World Bank). They also stated the companies in developing countries perceive little pressure from the general public regarding disclosure of CSR information.

The sampled companies mainly appear to report positive information and self-laudatory in nature. This result confirms the findings of the research where companies tend to disclose declarative or narrative disclosure and avoid reporting negative information (Hackston and Milne, 1996). In this way environmental disclosure seems to be a tool to maintain legitimacy (Cho and Patten, 2007; Cho et al., 2010). Companies aiming to gain or maintain legitimacy may use communication strategies including financial reports disclosures to influence social perceptions (Lindblom, 1994; Deegan, 2002). Companies' activities may affect a large number of stakeholders including shareholders, investors, customers, employees, and government etc. A company's long term survival depends on a firm's ability to legitimize its activities in the context where the company is operating. Thus, managers as a consequence attempt to manage public impressions through positive and self-laudatory disclosures.

Focusing on the environmental management strategies, financial firms paid little attention to the management of environmental issues. This may be attributed to low levels of pressures from various stakeholders regarding protection of environment as financial companies are not dealing with environmentally sensitive material. Further a small number of non-financial companies in Pakistan followed proactive environmental management strategies thus corporations in Pakistan appear to approach environmental problems with Band-Aid solutions despite highest media attention, huge settlement cost for environmental claims and increased emphasis to environmental matters in the world particularly in the developed countries. A little emphasis to proactive environmental management strategies by corporations may be attributed to a lack of public demand for environmental management, insufficiency of environmental regulations and weak law enforcement mechanisms in Pakistan. Recently the incorporation of environmental management agenda into the election manifesto by the political parties in Pakistan, particularly Pakistan Tareek-e-Insaf, has broadened the scope of corporations' obligations. Thus it is the right time for corporation to reconsider their environmental management efforts and to ascertain that they are fully prepared and protected. Previous scholarship have argued that the sustainability of long-term profits requires investment in preventive environmental management programmes and the failure to do so may leave a company at a disadvantage as compared to its 
counterparts with better foresight (see Hunt and Auster, 1990). The previous studies have also shown that the environmental disasters made by Shell Ltd. resulted in loss of alluring contracts regarding oil extraction (see Deegan and Unerman, 2011). Further consumers' repudiation of Exxon credit cards, due to the public reaction, after the Alaskan oil spill is another example showing that how an environmental disaster directly influenced corporate performance (Hunt and Auster, 1990). These findings suggest that companies operating in developing countries in general and Pakistan in particular need take proactive measures to handle environmental related issues in order to avoid future settlement cost.

This research is not free from limitations. The results of this research cannot be generalised to non-listed companies of Pakistan as this research analyses the annual reports of listed companies only. This research used data from the annual reports published in the year 2008 which is unable to present the current picture of environmental management practices of listed companies of Pakistan. The research also highlights some areas for the future research. This research mainly relies on the annual reports of corporations published in 2008, which may give the partial picture of corporate environmental disclosure. Thus the future research should use latest environmental disclosure data published in both the annual reports and on corporate websites. The future research should focus on the factors influencing the environmental disclosure. The understanding of such factors may help the policy makers to implement environmental management programs in the country. Further, future researcher should also compare the environmental disclosures practices of local and multinational companies. This will enable the researchers to trace out the impact of international exposure on environmental disclosure practices. Furthermore, they should collect the longitudinal data to determine the increase in environmental disclosure with the passage of time. The future research should also be focused on the other dimensions of CSR disclosure: human resource, products and consumers, and community involvement disclosure because focusing only on the environmental disclosure gives the partial picture of corporations' assumed social responsibilities.

\section{References}

Albertini, E. (2014). A Descriptive Analysis of Environmental Disclosure: A Longitudinal study of French companies. Journal of Business Ethics, 121(2), 233-254

Alcaraz-Quiles, F. J., Navarro-Galera, A., \& Ortiz-Rodríguez, D. (2014). Factors influencing the transparency of sustainability information in regional governments: An empirical study, Journal of Cleaner Production, 82(1), 179-191.

Amran, A., \& Devi, S. S. (2007). Corporate social reporting in Malaysia: A political theory perspective. Malaysian Accounting Review, 6(1), 19-44.

Amran, A., \& Devi, S. S. (2008). The impact of government and foreign affiliate influence on corporate social reporting: The case of Malaysia. Managerial Auditing Journal, 23(4), 386-404.

Asian Development Bank. (2006). Country synthesis report on urban air quality management: Pakistan. Philippines: Asian Development Bank and the Clean Air Initiative for Asian Cities (CAI-Asia) Centre.

Belal, A. R. (2001). A study of corporate social disclosures in Bangladesh. Managerial Auditing Journal, 16(5), 274-289.

Belal, A. R., \& Cooper, S. (2011). The absence of corporate social responsibility reporting in Bangladesh. Critical Perspectives on Accounting, 22(7), 654-667.

Belal, A. R., \& Momin, M. (2009). Corporate social reporting (CSR) in emerging economies: a review and future direction. Research in accounting in emerging economies, 9, 119-143.

Belal, A. R., \& Owen, D. L. (2007). The views of corporate managers on the current state of, and future prospects for, social reporting in Bangladesh: An engagement-based study. Accounting, Auditing \& Accountability Journal, 20(3), 472-494.

Bouten, L., Everaert, P., Van Liedekerke, L., De Moor, L., \& Christiaens, J. (2011). Corporate social responsibility reporting: A comprehensive picture? Accounting Forum, 35(3), 187-204.

Branco, M. C., \& Rodrigues, L. L. (2008). Factors influencing social responsibility disclosure by Portuguese companies. Journal of Business Ethics, 83(4), 685-701. 
Brown, N., \& Deegan, C. (1998). The public disclosure of environmental performance information-a dual test of media agenda setting theory and legitimacy theory. Accounting and Business Research, 29(1), 21-41.

Chiu, T., \& Wang, Y. (2014). Determinants of social disclosure quality in Taiwan: An application of stakeholder theory. Journal of Business Ethics, 121(1), 1-20.

Christmann, P., \& Taylor, G. (2002). Globalization and the environment: Strategies for international voluntary environmental initiatives. Academy of Management Executive, 16(3), 121-135.

Clarkson, M. E. (1995). A stakeholder framework for analyzing and evaluating corporate social performance. Academy of Management Review, 20(1), 92-117.

Cormier, D., \& Magnan, M. (2003). Environmental reporting management: A continental European perspective. Journal of Accounting and Public Policy, 22(1), 43-62.

Cormier, D., Magnan, M., \& Van Velthoven, B. (2005). Environmental disclosure quality in large German companies: Economic incentives, public pressures or institutional conditions? European Accounting Review, 14(1), 3-39.

Cowen, S. S., Ferreri, L. B., \& Parker, L. D. (1987). The impact of corporate characteristics on social responsibility disclosure: A typology and frequency-based analysis. Accounting, Organizations and society, 12(2), 111-122.

CSR Order. (2009). Companies (Corporate Social Responsibility) General Order, 2009 by Securities and Exchange Commission of Pakistan

De Villiers, C. J. (2003). Why do South African companies not report more environmental information when managers are so positive about this kind of reporting?. Meditari Accountancy Research, 11(1), 11-23.

De Villiers, C., \& Van Staden, C. J. (2006). Can less environmental disclosure have a legitimising effect? Evidence from Africa. Accounting, Organizations and Society, 31(8), 763-781.

Deegan, C., \& Gordon, B. (1996). A study of the environmental disclosure practices of Australian corporations. Accounting and business research, 26(3), 187-199.

Deegan, C., \& Unerman, J. (2011). Financial accounting theory (2nd ed.). London: McGraw-Hill.

Deegan, C., Rankin, M., \& Voght, P. (2000). Firms' disclosure reactions to major social incidents: Australian evidence. Accounting Forum, 24(1), 101-130.

Dowling, J., \& Pfeffer, J. (1975). Organizational legitimacy social values and organizational behaviour. Pacific Sociological Review, 18(1), 122-136.

Elijido-Ten, E. (2009). Can stakeholder theory add to our understanding of Malaysian environmental reporting attitudes? Malaysian Accounting Review, 8(2), 85-110.

Fifka, M. S. (2013). Corporate Responsibility Reporting and its Determinants in Comparative Perspective-a Review of the Empirical Literature and a Meta-analysis. Business Strategy and the Environment, 22(1), 1-35.

Gao, S. S., Heravi, S., \& Xiao, J. Z. (2005). Determinants of corporate social and environmental reporting in Hong Kong: A research note. Accounting Forum, 29(2), 233-242.

Ghazali, N. A. (2007). Ownership structure and corporate social responsibility disclosure: some Malaysian evidence. Corporate Governance: The international journal of business in society, 7(3), 251-266.

Gray, R., Kouhy, R., \& Lavers, S. (1995). Corporate social and environmental reporting: a review of the literature and a longitudinal study of UK disclosure. Accounting, Auditing \& Accountability Journal, 8(2), 47-77.

Gray, R., Kouhy, R., \& Lavers, S. (1995a). Corporate social and environmental reporting: A review of the literature and a longitudinal study of UK disclosure. Accounting, Auditing \& Accountability Journal, 8(2), 47-77.

Gray, R., Owen, D., \& Adams, C. (1996). Accounting and accountability: Changes and challenges in corporate social and environmental reporting. London: Prentice-Hall.

Guthrie, J., \& Parker, L. D. (1989). Corporate social reporting: A rebuttal of legitimacy theory. Accounting \& Business Research, 19(76), 343-352.

Hackston, D., \& Milne, M. J. (1996). Some determinants of social and environmental disclosures in 
New Zealand companies. Accounting, Auditing \& Accountability Journal, 9(1), 77-108.

Haji, A. A. (2013). Corporate social responsibility disclosures over time: Evidence from Malaysia. Managerial Auditing Journal, 28(7), 647-676.

Halme, M., \& Huse, M. (1997). The influence of corporate governance, industry and country factors on environmental reporting. Scandinavian Journal of Management, 13(2), 137-157.

Haniffa, R. M., \& Cooke, T. E. (2005). The impact of culture and governance on corporate social reporting. Journal of Accounting \& Public Policy, 24(5), 391-430.

Hassel, L., Nilson, H., \& Nyquist, S. (2005). The value relevance of environmental performance. European Accounting Review, 14(1), 41-61.

Huang, C., \& Kung, F. (2010). Drivers of environmental disclosure and stakeholder expectation: Evidence from Taiwan. Journal of Business Ethics, 96(3), 435-451.

Hunt, C. B., \& Auster, E. R. (1990). Proactive environmental management: Avoiding the toxic trap. Sloan Management Review, 31(2), 7-18.

Islam, M. A., \& Deegan, C. (2008). Motivations for an organisation within a developing country to report social responsibility information. Accounting, Auditing \& Accountability Journal, 21(6), 850-874.

Kamla, R. (2007). Critically Appreciating Social Accounting and Reporting in the Arab Middle East: A Postcolonial Perspective. Advances in International Accounting, 20(1), 105-177.

Kansal, M., Joshi, M., \& Batra, G. S. (2014). Determinants of corporate social responsibility disclosures: Evidence from India. Advances in Accounting, 30(1), 217-229.

Khan, A., Muttakin, M. B., \& Siddiqui, J. (2013). Corporate governance and corporate social responsibility disclosures: Evidence from an emerging economy. Journal of business ethics, 114(2), 207-223.

Laan Smith, J., Adhikari, A., \& Tondkar, R. H. (2005). Exploring differences in social disclosures internationally: A stakeholder perspective. Journal of Accounting and Public Policy, 24(2), 123151.

Lindblom, C. K. (1993). The implications of organizational legitimacy for corporate social performance and disclosure. Critical Perspectives on Accounting Conference, New York.

Lorraine, N. H., Collison, D. J., \& Power, D. M. (2004). An analysis of the stock market impact of environmental performance information. Accounting Forum, 28(1), 7-26.

Lund-Thomsen, P., \& Nadvi, K. (2010). Global value chains, local collective action and corporate social responsibility: A review of empirical evidence. Business Strategy and the Environment, 19(1), 113.

Lund-Thomsen, P., Mansur, A., \& Lotia, H. (2006). Corporate social responsibility and sustainability of donor-financed interventions in the south: The case of Pakistan. Corporate Citizenship in Developing Countries, Copenhagen Business School Press, Copenhagen

Mahadeo, J. D., Oogarah-Hanuman, V., \& Soobaroyen, T. (2011b). Changes in social and environmental reporting practices in an emerging economy (2004-2007): Exploring the relevance of stakeholder and legitimacy theories. Accounting Forum, 35(3), 158-175.

Mahadeo, J., Oogarah-Hanuman, V., \& Soobaroyen, T. (2011). A longitudinal study of corporate social disclosures in a developing economy. Journal of Business Ethics, 104(4), 545-558.

Mitchell, C. G., \& Hill, T. (2009). Corporate social and environmental reporting and the impact of internal environmental policy in South Africa. Corporate Social Responsibility and Environmental Management, 16(1), 48-60.

Newson, M., \& Deegan, C. (2002). Global expectations and their association with corporate social disclosure practices in Australia, Singapore, and South Korea. The International Journal of Accounting, 37(2), 183-213.

O'Donovan, G. (2002). Environmental disclosures in the annual report: Extending the applicability and predictive power of legitimacy theory. Accounting, Auditing \& Accountability Journal, 15(3), 344-371.

O'Dwyer, B. (2002). Managerial perceptions of corporate social disclosure: An Irish story. Accounting, Auditing \& Accountability Journal, 15(3), 406-436. 
Pakistan Bureau of Statistics. (2011). Pakistan statistical year book 2011. Islamabad: Government of Pakistan.

PEPA. (2005a). Brief of environmental concerns-Pakistan scenario. Islamabad: Pakistan Environmental Protection Agency.

Rahaman, A. S., Lawrence, S., \& Roper, J. (2004). Social and environmental reporting at the VRA: Institutionalised legitimacy or legitimation crisis? Critical Perspectives on Accounting, 15(1), 35-56.

Ratanajongkol, S., Davey, H., \& Low, M. (2006). Corporate social reporting in Thailand: The news is all good and increasing. Qualitative Research in Accounting \& Management, 3(1), 67-83.

Reverte, C. (2009). Determinants of corporate social responsibility disclosure ratings by Spanish listed firms. Journal of Business Ethics, 88(2), 351-366.

Roome, N. (1992). Developing environmental management strategy. Business Strategy and the Environment, 1(1), 11-24.

Savage, A. A. (1994). Corporate social disclosure practices in South Africa: A research note. Social and Environmental Accounting, 14(1), 2-4.

SDPI (2012). Environmental challenges and constraints to policy issues for sustainable industrial development in Pakistan. Islamabad, Pakistan: Sustainable Development Policy Institute.

SECP. (2011). Securities and Exchange Commission of Pakistan annual report 2011. Karachi, Pakistan: Securities and Exchange Commission of Pakistan.

SECP. (2014). The company law division: Securities and exchange commission of pakistan. Retrieved February 14, 2014, Retrieved from http://www.secp.gov.pk/CLD/cld_index.asp

Seppanen, M. (2009). Empirical classification of resources in a business model concept. Intangible Capital, 5(2), 102-124.

Shocker, A., \& Sethi, S. (1974). An approach to incorporating social preferences in developing corporate action strategies, in Sethi, S. P. (ed.) the unstable ground: Corporate social policy in a dynamic society. Melville: California. pp 67-80.

Singh, D. R., \& Ahuja, J. M. (1983). Corporate social reporting in India. The International Journal of Accounting, 18(2), 151-169.

Sobhani, F. A., Amran, A., \& Zainuddin, Y. (2009). Revisiting the practices of corporate social and environmental disclosure in Bangladesh. Corporate Social Responsibility \& Environmental Management, 16(3), 167-183.

Suchman, M. C. (1995). Managing legitimacy: Strategic and institutional approaches. Academy of Management Review, 20(3), 571-610.

Tagesson, T., Blank, V., Broberg, P., \& Collin, S. (2009). What explains the extent and content of social and environmental disclosures on corporate websites: A study of social and environmental reporting in Swedish listed corporations? Corporate Social Responsibility \& Environmental Management, 16(6), 352-364.

Thomas, A. (2001). Corporate environmental policy and abnormal stock price returns: An empirical investigation. Business Strategy and the Environment, 10(3), 125-134.

Tsang, E. W. (1998). A longitudinal study of corporate social reporting in Singapore: The case of the banking, food and beverages and hotel industries. Accounting, Auditing \& Accountability Journal, 11(5), 624-635.

Van Staden, C. J., \& Hooks, J. (2007). A comprehensive comparison of corporate environmental reporting and responsiveness. British Accounting Review, 39(3), 197-210.

Vuontisjärvi, T. (2006). Corporate social reporting in the European context and human resource disclosures: An analysis of Finnish companies. Journal of Business Ethics, 69(4), 331-354.

Wanderley, L., Lucian, R., Farache, F., \& Sousa Filho, J. (2008). CSR information disclosure on the web: A context-based approach analysing the influence of country of origin and industry sector. Journal of Business Ethics, 82(2), 369-378.

Williams, S. M. (1999). Voluntary environmental and social accounting disclosure practices in the AsiaPacific region: An international empirical test of political economy theory. The International Journal of Accounting, 34(2), 209-238. 